\title{
Trait Association and Path Analysis Studies for Yield Traits in Recombinant Inbred Lines Derived from Cross KP $\times A-69-1$ in Rice (Oryza sativa L.)
}

\section{Sanchika Snehi ${ }^{1 \searrow(0)}$, Prachi Pandey ${ }^{1}$, S. R. Rathi ${ }^{1}$, Pallavi ${ }^{2,3}$, P. K. Singh ${ }^{1}$ and Sameer Upadhyay ${ }^{1}$}

${ }^{1}$ Dept. of Genetics and Plant Breeding, Institute of Agricultural Sciences, Banaras Hindu University (BHU), Varanasi, Uttar Pradesh (221 005), India

${ }^{2}$ Karlsruhe Institute of Technology (KIT), Botanical Institute Fritz-Haber-Weg 4, Building 30.43, Karlsruhe (76131), Germany ${ }^{3}$ IRRI South Asia Regional Center, NSRTC Campus, Varanasi, Uttar Pradesh (221 106), India

Open Access

Corresponding $\$ sanchikasnehi26@gmail.com

0000-0002-5777-3421

\section{ABSTRACT}

S tudies pertaining to genetic variability, trait association and correlation among yield traits give elementary idea about the $\mathcal{S}_{\text {amount }}$ and direction of genetic association of the traits in the population and devising appropriate breeding methods for further improvement of the crop. This study aimed to estimate coefficients of variability, genetic advance, heritability, trait association and path coefficient analysis among 40 recombinant inbred lines $\left(\mathrm{F}_{7}\right)$ derived from biparental cross $(\mathrm{KP} \times \mathrm{A}-69-1)$. These lines were evaluated for yield and its contributing traits in randomised complete block design (RCBD) during kharif-2018. High estimates of Genotypic Coefficient of Variations (GCV) and Phenotypic Coefficient of Variations (PCV) were observed for filled grain panicle ${ }^{-1}$ followed by total grain panicle ${ }^{-1}$, number of effective tillers plant ${ }^{-1}$, panicle weight and grain yield plant ${ }^{-1}$. High heritability conjugated with high genetic advance were recorded for plant height and filled grains panicle ${ }^{-1}$. Panicle weight, filled grain panicle ${ }^{-1}$, number of effective tillers plant ${ }^{-1}$ and panicle length showed positive and significant $(p \leq 0.01)$ correlation with grain yield plant ${ }^{-1}$. Path coefficient analysis showed that despite significant and positive correlation of grain yield plant ${ }^{-1}$ with many variables only correlation of panicle weight and number of effective tillers plant ${ }^{-1}$ were verified to have relationship of cause and effect. Overall result gesture towards role of panicle weight, number of effective tillers plant ${ }^{-1}$ and filled grains panicle $^{-1}$ as important variables for use in grain yield plant ${ }^{-1}$ assessment programs as selection indices.

KEYWORDS: Correlation, genetic advance, heritability, path coefficient analysis, rice, yield

Citation (VANCOUVER): Snehi et al., Trait Association and Path Analysis Studies for Yield Traits in Recombinant Inbred Lines Derived from Cross KP×A-69-1 in Rice (Oryza sativa L.). International Journal of Bio-resource and Stress Management, 2022; 13(1), 22-28. HTTPS:// DOI.ORG/10.23910/1.2022.2661b.

Copyright: (c) 2022 Snehi et al. This is an open access article that permits unrestricted use, distribution and reproduction in any medium after the author(s) and source are credited.

Data Availability Statement: Legal restrictions are imposed on the public sharing of raw data. However, authors have full right to transfer or share the data in raw form upon request subject to either meeting the conditions of the original consents and the original research study. Further, access of data needs to meet whether the user complies with the ethical and legal obligations as data controllers to allow for secondary use of the data outside of the original study.

Conflict of interests: The authors have declared that no conflict of interest exists.

RECEIVED on 07th 0 ctober 2021 RECEIVED in revised form on $05^{\text {th }}$ January 2022 ACCEPTED in final form on $21^{\text {st }}$ January 2022 PUBLISHED on $25^{\text {th }}$ January 2022 


\section{INTRODUCTION}

$\mathrm{R}^{\mathrm{i}}$ ice (Oryza sativa L.) is a worldwide important cereal crop, and as a most important source of food it accounts for $35-75 \%$ of the calorie intake of $>3.5$ billion humans (Krishnamurthy et al., 2016). The genus Oryza (including both cultivated and wild rice species) can grow in diverse climatic conditions and locations from the wettest areas to the driest deserts in the world's geographic distribution extending from $50^{\circ} \mathrm{N}-35^{\circ} \mathrm{S}$ (Pathak et al., 2018). World's population is increasing and will reach toward 10 billion by 2050 , and by then demand for rice will grow faster than other crops. Presently, productivity of rice is increasing at the rate of $1 \%$ year $^{-1}$, which should be increased at the rate of $2.4 \%$ to feed the growing population by 2050 (Varshney et al., 2011; Prince et al., 2015; Rejeth et al., 2020). According to FAO, India produced $118.93 \mathrm{mt}$ of milled rice on $45 \mathrm{mha}$ area in the year 2020 (Anonymous, 2020). Uttar Pradesh being key rice producing state has $5.74 \mathrm{mha}$ under rice cultivation, producing $15.52 \mathrm{mt}$ rice during 2020 (Anonymous, 2020). Being a staple food for more than $56 \%$ of global population and livelihood source for nearly $40 \%$ rural households globally, refining grain yield of this strategic crop has become climacteric (Pathak et al., 2019).

Improvement of yield requires an in-depth knowledge of the magnitude of variation present in the available germplasm, interdependence of quantitative characters with yield, extent of environmental influence on these factors, heritability and genetic gain of the material (Bhargava et al., 2007). Phenotypic coefficient of variation (PCV) provide insight into the role of genotypic as well as environment in the phenotypic expression of the trait while, heritable variability is estimated by the genotypic coefficient of variation (GCV). Other important selection parameters are heritability and genetic advance. During selection, the traits to be taken into consideration are determined by using the estimates of heritability. For predicting the gain under selection and for selecting superior varieties the parameters to be considered are estimates of heritability and genetic advance (Ali et al., 2002; Dey et al., 2021; Vennela et al., 2021). A correlation study provides trustworthy and helpful information about the type, scope, and direction of selection (Zeeshan et al., 2013). The coefficient of correlations aids in determining the level of relationship between two separate traits as well as the level at which these traits are mutually variable (Bocanski et al., 2009; Nagabhushan et al., 2011). Examining this relationship between quantitative traits is an important task of assessing the feasibility of a joint selection of two or more traits instead of selecting the secondary traits as genetic gains for primary traits under consideration (Ezeaku and Muhammad, 2006). Association studies confer an idea about relative contribution of different traits in manifesting yield and magnitude of correlation between yield component and yield and among themselves (Vennela et al., 2021). Consequently, an insight into interrelationships existing amidst yield components is needed, for selection to be effective. Correlation studies alone fails to depict the clear picture with respect to the association among traits. Path analysis determine the yield components, directly or indirectly influencing the yield (Das et al., 2020). The present investigation was undertaken in this context to elucidate information on variability, heritability, genetic advance, character associations and path of effect in forty zinc deficiency tolerant recombinant rice lines (RILs) of $\mathrm{F}_{7}$ generation. A sound knowledge of genetic resources might also help in identifying promising genotypes for future hybridization program.

\section{MATERIALS AND METHODS}

$\mathrm{T}$ he research work was conducted at the research farm of the Institute of Agricultural Sciences, Banaras Hindu University, Varanasi $\left(25.2677^{\circ} \mathrm{N}, 82.9913^{\circ} \mathrm{E}\right.$; Altitude $80.71 \mathrm{~m}$ ) during the kharif (June-November) season of 2018. The field experiment was conducted in randomized complete block design (RCBD) in three replications with a spacing of $10 \mathrm{~cm}$ and $15 \mathrm{~cm}$ between plants and rows respectively.

\subsection{Plant Material and morphological observations}

The study comprised of forty $\mathrm{F}_{7}$ Recombinant Inbred Lines (RILs) derived from the crosses between the two parents Kinandang Patong (high yielding, tropical japonica, sensitive to zinc deficiency tolerance) and A69-1 (indica variety, tolerant to zinc deficiency) by single seed descent method. Recommended package of practices were followed for all the entries in order to raise a good crop. Each $F_{7}$ plant was harvested separately and observed for traits like Days to $50 \%$ flowering [DF], Days to maturity [DM], Plant height $(\mathrm{cm})[\mathrm{PH}]$, Panicle length $(\mathrm{cm})[\mathrm{PL}]$, Effective tillers plant $^{-1}[\mathrm{ET}]$, Filled grains panicle ${ }^{-1}[\mathrm{FGP}]$, Unfilled grains panicle $^{-1}$ [UGP], Total grains panicle ${ }^{-1}$ [TGP], Spikelet Fertility percentage [SF], Test weight (g) [TW] and Grain yield plant ${ }^{-1}(\mathrm{~g})$ [GYP].

\subsection{Statistical analysis of data}

The data generated were subjected to analysis of variance (ANOVA) for Randomized Complete Block Design (RCBD) as defined by Panse and Sukhatme (1967). Variability parameter such as mean, range and standard error were calculated as per Singh and Choudhary (1977). Coefficient of variation (such as genotypic and phenotypic variation), heritability and genetic advance were estimated for the different characters as follows. Phenotypic and genotypic coefficient of variation (PCV and GCV) were calculated by the method suggested by Burton and Devane 
(1953). PCV and GCV were classified according to Robinson et al. (1966) as follows, 0-10\% -Low, 10-20\% -Moderate, $>20 \%$-High. Heritability is the proportion of genetic variance to the phenotypic variance and expressed in percentage (\%). It was calculated by the formula as given by Allard (1990). Heritability percentage was categorized as per scale given by Robinson et al. (1966), as 0-30\% -Low, 30-60\% -Moderate, >60\% -High. The Genetic Advance as percentage of mean was classified as per scale given by Johnson et al. (1955) as 0-10\% - Low, 10-20\% - Moderate, $>20 \%$-High. The correlation coefficients were calculated to determine the degree of association of characters with yield as suggested by Searle (1961). The significance of correlation coefficients was tested against ' $r$ ' values given by Fisher and Yates (1963). The path coefficients were obtained according to Dewey and $\mathrm{Lu}$ (1959). Grain yield was considered to be dependent variable (effect) which is affected by all other (eleven) independent variables (cause), directly as well as indirectly through other characters. The variation in grain yield unexplained by the traits under consideration was supposed to be contributed by a residual factor which is uncorrelated with other factors.

\section{RESULTS AND DISCUSSION}

A nalysis of variance (ANOVA) for the design of experiment was implied for all the twelve traits studied for appraising 40 treatments. The mean sum of squares due to treatments were found to be significant for all the twelve traits studied (Table 1). Existence of genetic variability is of paramount significance for improvement of any crop. A perusal of GCV and PCV revealed that, GCV and PCV for yield traits were highest for filled grain panicle ${ }^{-1}(26.83$ and $34.27)$ followed by total grain panicle ${ }^{-1}(20.87$ and 27.65$)$ and number of effective tillers plant ${ }^{-1}$ (22.10 and 26.77).

Table 1: Analysis of variance (ANOVA) for twelve (12) yield and yield related traits for 40 Recombinant Inbreds Lines (RILs)

\begin{tabular}{|c|c|c|c|c|c|c|c|c|c|c|c|c|c|}
\hline \multirow{2}{*}{$\begin{array}{l}\text { Source of } \\
\text { variation }\end{array}$} & \multirow{2}{*}{ df } & \multicolumn{12}{|c|}{ Mean sum of squares } \\
\hline & & DF & $\mathrm{DM}$ & $\mathrm{PH}$ & ET & PL & FGP & UGP & TGP & TW & GYPP & PW & SF\% \\
\hline $\begin{array}{l}\text { Replica- } \\
\text { tion }\end{array}$ & 2 & 0.61 & 6.10 & 2.73 & 0.17 & 11.06 & 73.95 & 701.30 & 1222.33 & 0.17 & 23.49 & 1.78 & 353.22 \\
\hline $\begin{array}{l}\text { Treat- } \\
\text { ment }\end{array}$ & 39 & $76.97^{* *}$ & $87.71^{* *}$ & $633.63^{* *}$ & $8.61^{* *}$ & $34.32^{* *}$ & $3065.51^{* *}$ & $969.80^{* *}$ & $3273.63^{* *}$ & $16.03^{* *}$ & $27.00^{* *}$ & $1.14^{* *}$ & $327.00^{* *}$ \\
\hline Error & 78 & 7.89 & 8.54 & 22.67 & 1.76 & 4.60 & 532.84 & 148.31 & 658.78 & 3.43 & 6.84 & 0.20 & 87.89 \\
\hline
\end{tabular}

df: Degree of freedom; DF: Days to 50\% flowering; DM: Days to Maturity; PH: Plant height; ET: Number of effective tillers plant $^{-1}$; PL: Panicle length; FGP: Filled grains panicle ${ }^{-1}$; UGP: Unfilled grains panicle ${ }^{-1}$; TGP: Total grains panicle ${ }^{-1}$; TW: Test weight; GYPP: Grain yield plant ${ }^{-1}$; PW: Panicle weight; SF \%: Spikelet fertility percentage

High GCV and PCV for filled grain panicle ${ }^{-1}$, total grain panicle ${ }^{-1}$ and number of effective tillers plant ${ }^{-1}$ indicated that selection for these traits would be rewarding. These results are in agreement with Abebe et al. (2017). The GCV and PCV were the lowest for days to maturity (4.45 and 5.11) and days to flowering (5.71 and 6.62). Similarly, Singh et al. (2015) in their studies on 38 germplasm accessions reported highest estimates of GCV and PCV for total grain panicle ${ }^{-1}$ followed by grain yield plot $^{-1}$, test weight and total number of tillers plant ${ }^{-1}$, and lowest in spikelet fertility followed by kernel breadth, days to $50 \%$ flowering and panicle length. PCV were slightly higher than GCV in case of all the traits, indicating substantial role of environment in the phenotypic expression of these traits. The above results (Table 2) were also evident from the studies of Rashid et al. (2017).

Since mere existence of variability does not guarantee the transmission to the progeny, hence estimates of heritability in broad sense $\left(\mathrm{h}_{\mathrm{bs}}^{2}\right)$ were also worked out for the traits (Table 2). The parameter contemplates the prospects of phenotype-based selection. The set of the materials studied exhibited moderate to high heritability (broad sense) for all the traits studied as also reported by Fukrei et al. (2011) and Rashid et al. (2017), High heritability does not always guarantee high genetic gain. High heritability combined with high genetic advance is an indicative of additive gene action and selection based on these parameters would be more reliable (Johnson, 1955). Therefore, heritability and genetic advance should be considered together. High heritability conjugated with high genetic advance were recorded for filled grains panicle ${ }^{-1}$, panicle weight and panicle length. Similar result for these traits was reported by and Fukrei et al. (2011). On the contrary, high heritability and low genetic advance were observed for days to maturity and days to $50 \%$ flowering manifesting the preponderance of non-additive gene action and role of genotypexenvironment interactions in the phenotypic expression of these traits. Similar result was observed by Akinwale et al. (2011) and Singh et al. (2015) for days to maturity.

Trait association studies between yield and yield component are advantageous in selection of desirable plant type for 


\begin{tabular}{|c|c|c|c|c|c|c|}
\hline Traits & $\mathrm{DF}$ & $\mathrm{DM}$ & $\mathrm{PH}$ & ET & PL & FGP \\
\hline Mean \pm SE & $84.02 \pm 1.62$ & $115.57 \pm 1.69$ & $110.53 \pm 2.75$ & $7.51 \pm 0.77$ & $23.42 \pm 1.24$ & $108.29 \pm 13.33$ \\
\hline Range & $73.33-94.33$ & $104.33-127.00$ & $83.97-150.43$ & $4.00-13.70$ & $15.47-33.80$ & $55.20-199.67$ \\
\hline PCV (\%) & 6.62 & 5.11 & 13.61 & 26.78 & 16.27 & 34.27 \\
\hline $\mathrm{GCV}(\%)$ & 5.71 & 4.44 & 12.91 & 20.10 & 13.44 & 26.83 \\
\hline $\mathrm{h}^{2}(\%)$ broad sense & 74.50 & 75.50 & 90.00 & 56.40 & 68.30 & 61.30 \\
\hline $\mathrm{GA}$ as $\%$ mean $(\mathrm{K}=2.06)$ & 10.51 & 7.96 & 25.23 & 31.10 & 22.87 & 43.28 \\
\hline \multicolumn{7}{|l|}{ Table 2: Continue... } \\
\hline Traits & UGP & TGP & TW & GYPP & PW & $\mathrm{SF} \%$ \\
\hline Mean \pm SE & $33.64 \pm 7.03$ & $141.47 \pm 14.82$ & $23.00 \pm 1.07$ & $17.93 \pm 1.51$ & $2.68 \pm 0.26$ & $76.19 \pm 5.41$ \\
\hline Range & $5.57-88.00$ & $64.93-203.80$ & $16.62-28.43$ & $9.31-23.22$ & $1.44-4.57$ & $51.76-93.49$ \\
\hline $\mathrm{PCV}(\%)$ & 61.07 & 27.65 & 12.01 & 20.54 & 26.76 & 16.99 \\
\hline GCV (\%) & 49.19 & 20.87 & 8.91 & 14.46 & 20.94 & 11.72 \\
\hline $\mathrm{h}^{2}(\%)$ broad sense & 64.90 & 57.00 & 55.00 & 49.60 & 61.20 & 47.60 \\
\hline $\mathrm{GA}$ as $\%$ mean $(\mathrm{K}=2.06)$ & 81.61 & 32.44 & 13.62 & 20.98 & 33.76 & 16.64 \\
\hline
\end{tabular}

effective breeding programme (Das et al., 2020). Yield being complex trait is resultant of multiplicative interaction of different traits referred to as yield components. Hence, genetic architect of yield in rice and other crops is resultant of the balance or overall net effect manifested by various yield components directly or in interaction with one to other. Consequently, identification of significant yield components and information about their association with yield and also with each other is crucial for designing efficient breeding program in order to breed high yielding varieties. Henceforth, correlation coefficient which bestow symmetrical measurement regarding degree of association between two variables or traits assist in elucidating the nature and magnitude of association among yield and yield components. The correlation coefficients with grain yield plant ${ }^{-1}$ vis-a-vis other yield components and their allpossible interrelationships are presented in (Figure 1). The grain yield plant ${ }^{-1}$ manifested significant positive correlation with panicle weight $\left(0.40^{* *}\right)$, filled grain panicle ${ }^{-1}\left(0.37^{* *}\right)$, effective tillers plant ${ }^{-1}\left(0.32^{* *}\right)$, panicle length $\left(0.31^{* *}\right)$, spikelet fertility percentage $\left(0.27^{\prime \prime \prime}\right)$ and plant height $\left(0.25^{* \prime \prime}\right)$ (Table 3). This is in consonant with earlier findings on rice with Bhati et al. (2015), Roy et al. (2015) for plant height and filled grains panicle ${ }^{-1}$ and Singh et al. (2013) for filled grains panicle ${ }^{-1}$. Total grain panicle ${ }^{-1}$ exhibited nonsignificant but positive correlation with grain yield. These results were in conformity with the previous results of Allam et al. (2015). Similarly, spikelet fertility percentage exhibited significant positive correlation with filled grain panicle ${ }^{-1}$ $\left(0.36^{* *}\right)$, nevertheless, spikelet fertility percentage exhibited negative correlation with unfilled grain panicle ${ }^{-1}\left(-0.82^{* \prime}\right)$,

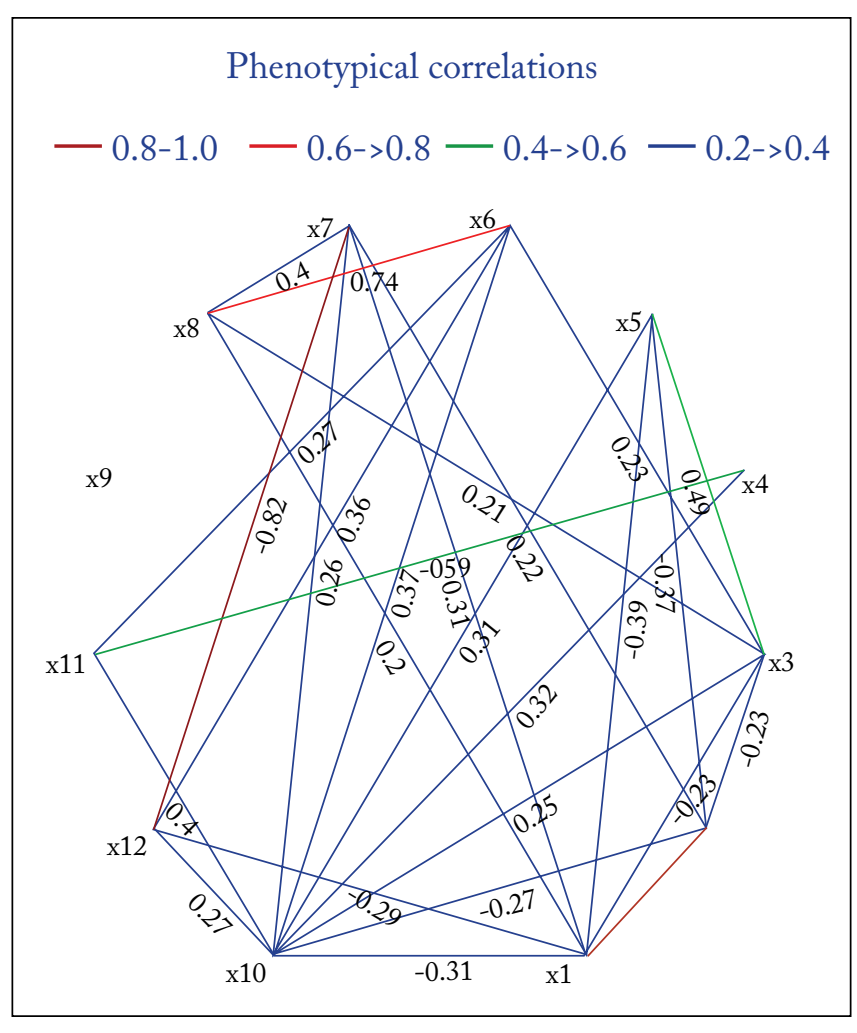

Figure 1: Phenotypic correlations between yield and yield attributing traits

days to $50 \%$ flowering $(-0.28 \%)$ and days to maturity $\left(-0.18^{* *}\right)$. Panicle weight showed positive correlation with filled grain panicle ${ }^{-1}\left(0.27^{\text {*t*}}\right)$. Total grain panicle ${ }^{-1}$ showed positive correlation with filled grain panicle ${ }^{-1}\left(0.74^{* *}\right)$, unfilled grain panicle ${ }^{-1}\left(0.41^{* *}\right)$, plant height $\left(0.21^{*}\right)$, days to 
Table 3: Estimates of phenotypic correlation among yield and yield related traits in rice

\begin{tabular}{|c|c|c|c|c|c|c|c|c|c|c|c|}
\hline Traits & DM & $\mathrm{PH}$ & ET & PL & FGP & UGP & TGP & TW & PW & $\mathrm{SF} \%$ & GYPP \\
\hline DF & $0.89^{*+*}$ & $-0.23^{*}$ & $-0.18^{*}$ & $0.39^{* * *}$ & -0.12 & $0.31^{* *}$ & $0.20^{*}$ & -0.10 & 0.11 & $0.28^{* * *}$ & $0.31^{* * *}$ \\
\hline DM & & $-0.25^{*}$ & $0.19^{*}$ & $0.37^{* * *}$ & 0.11 & $0.22^{*}$ & 0.16 & -0.08 & 0.18 & $-0.18^{*}$ & $0.27^{\text {tat }}$ \\
\hline $\mathrm{PH}$ & & & -0.01 & $0.49^{* * *}$ & $0.23^{*}$ & -0.01 & $0.21^{*}$ & 0.16 & 0.11 & 0.04 & $0.25^{\text {st }}$ \\
\hline ET & & & & 0.16 & 0.01 & 0.01 & 0.01 & 0.03 & $0.59^{* * *}$ & -0.02 & $0.32^{\text {s* }}$ \\
\hline PL & & & & & 0.12 & -0.10 & 0.03 & 0.15 & -0.01 & 0.13 & $0.31^{\text {*t }}$ \\
\hline FGP & & & & & & -0.06 & $0.74^{* * *}$ & -0.18 & $0.27^{\text {t** }}$ & $0.36^{* *}$ & $0.37^{\text {t*t }}$ \\
\hline UGP & & & & & & & $0.40^{* *+}$ & 0.15 & -0.09 & $0.82^{* *}$ & $0.26^{* *}$ \\
\hline TGP & & & & & & & & -0.06 & 0.16 & 0.01 & 0.13 \\
\hline TW & & & & & & & & & 0.01 & -0.08 & -0.02 \\
\hline PW & & & & & & & & & & 0.16 & $0.40^{* * *}$ \\
\hline $\mathrm{SF} \%$ & & & & & & & & & & & $0.27^{\text {tw }}$ \\
\hline
\end{tabular}

*: Significant at $p<0.05 ; * *$ Significant at $p<0.01$

flowering $\left(0.20^{*}\right)$. Panicle length showed significant positive correlation with days to maturity $\left(0.37^{* *}\right)$ and plant height $\left(0.49^{* *}\right)$ while manifested negative correlation with days to flowering $\left(0.39^{* *}\right)$. Filled grain panicle ${ }^{-1}$ showed positive correlation with plant height. Plant height manifested significant negative correlation with days to $50 \%$ flowering $\left(-0.23^{*}\right)$ and days to maturity $\left(-0.25^{*}\right)$. Days to $50 \%$ flowering manifested significant positive correlation $\left(0.89^{\text {**t }}\right)$ with days to maturity, unfilled grains panicle ${ }^{-1}$ and highly negative significant phenotypic correlation with the panicle length followed by grain yield panicle ${ }^{-1}$ and spikelet fertility percentage. The correlation studies provide ample scope for mutual improvement of traits via common selection.

Correlation alone frequently depicts misleading results when more traits are accounted in the correlation study. It might be possible that many of the traits may associate by virtue of mutual association, positive or negative, with other traits. Inclusion of more variables in the correlation studies further complicate their indirect association, thus, perplexing the selections. Under such situations, the path coefficient analysis proves to be an empathic tool for separating direct and indirect cause of association, thus allowing critical analysis of the specific forces operating to produce a given correlation and to appraise the relative proportion of each casual factor. The path coefficient analyses were carried out by using simple correlations between twelve characters to resolve direct and indirect effects of eleven different characters on grain yield plant ${ }^{-1}$.

Path coefficient analysis taking grain yield a dependent while other traits as independent variable is presented in (Figure 2). Direct and indirect path coefficient values manifest that panicle weight possessed maximum direct effect $\left(0.844^{* *}\right)$ followed by number of effective tillers plant ${ }^{-1}\left(0.767^{* * *}\right)$.

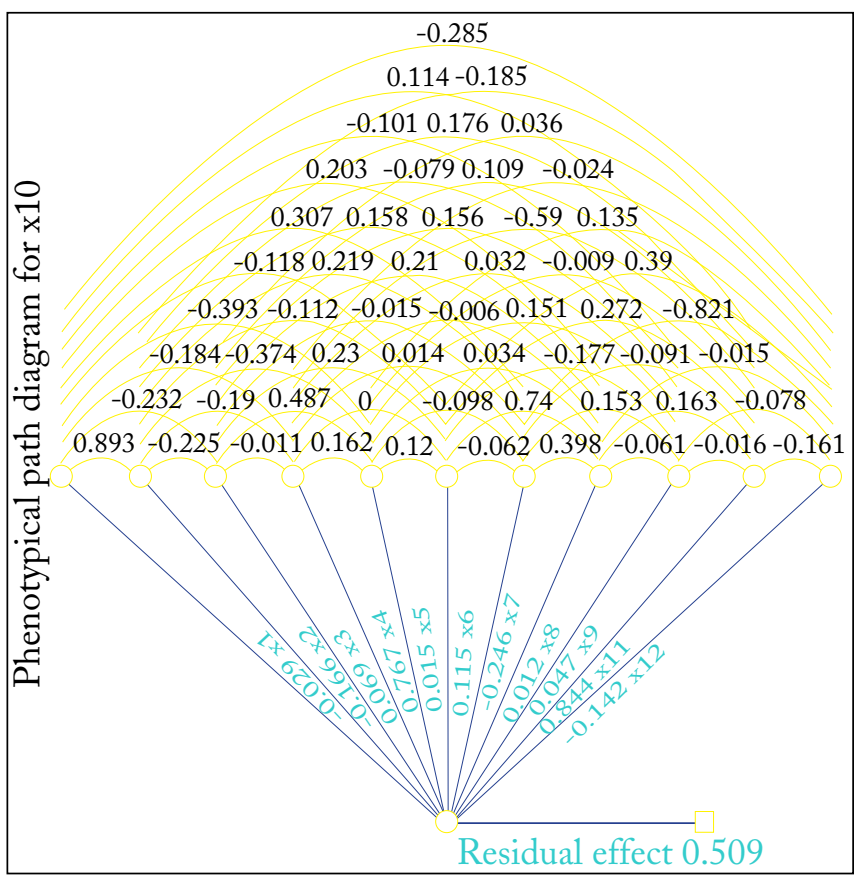

Figure 2: Phenotypic path analysis for different traits ( $\mathrm{x}$ : Days to 50\% flowering; x2: Days to Maturity; x3: Plant height; $x 4$ : Number of effective tillers plant ${ }^{-1} ; x 5$ : Panicle length; x6: Filled grains panicle ${ }^{-1}$; 7 : Unfilled grains panicle $^{-1}$; x8: Total grains panicle ${ }^{-1} ; \mathrm{x} 9$ : Test weight; x10: Grain yield plant $^{-1}$; $x 11$ : Panicle weight; x12: Spikelet fertility percentage

Positive direct effects of these traits on grain yield gestures toward their significance in determining yield plant ${ }^{-1}$. Henceforth, their inclusion in selection targeted to the improvement of grain yield would be rewarding. The other characters viz. plant height, panicle length, filled and total grains panicle ${ }^{-1}$ also showed positive direct effect but were 
found non-significantly correlated with grain yield. These results are in consonant with earlier findings of Chakraborty et al. (2001), Sudeepthi et al. (2020) and Singh et al. (2013) for total grains panicle ${ }^{-1}$.

Critical analysis of results obtained from character association and path analysis revealed that the panicle weight possessed both positive association and highest positive direct effects at phenotypic level followed by number of effective tillers. Hence, selection for these traits would be fruitful for improvement in yield and component characters. In view of the nature and magnitude of character association and their direct and indirect effects, it can be concluded that simultaneous improvement of grain yield plant ${ }^{-1}$ is possible through manifestation of plant height, number of effective tillers plant ${ }^{-1}$, panicle weight and number of filled grains panicle $^{-1}$. Further, the residual effect is 0.509 , which is high since the traits contribute only $49.1 \%$ to the variability in grain yield plant ${ }^{-1}$. Therefore, the result calls for inclusion of other traits which have not been studied, to account fully for the variation in grain yield.

\section{CONCLUSION}

$\mathrm{T}$ he present study indicated the scope of selection in the improvement of grain yield for the population studied and revealed the role of plant height, number of effective tillers plant ${ }^{-1}$, panicle weight and number of filled grains panicle $^{-1}$ in devising selection criteria for improving grain yield. It emphasized the need for balanced selection in light of negative correlation of panicle weight with effective tillers plant ${ }^{-1}$ in yield improvement programme in the set of material studied.

\section{REFERENCES}

Abebe, T., Alamerew, S., Tulu, L., 2017. Genetic variability, heritability and genetic advance for yield and its related traits in rainfed lowland rice (Oryza sativa L.) genotypes at Ethiopia. Advance Crop Science Technology 5, 272.

Akinwale, M.G., Gregorio, G., Nwilene, F., Akinyele, B.O., Ogunbayo, S.A., Odiyi, A.C., 2011. Heritability and correlation coefficient analysis for yield and its components in rice (Oryza sativa L.). African Journal of Plant Sciences 5(3), 207-212.

Ali, Z., Khan, A.S., Asad, M.A., 2002. Salt tolerance in bread wheat: Genetic variation and heritability for growth and ion relation. Asian Journal of Plant Sciences 1(4), 420-422.

Allam, C.R., Jaiswal, H.K., Qamar, A., 2015. Character association and path analysis studies of yield and quality parameters in basmati rice (Oryza sativa L.). Journal of progressive Agriculture 6(1), 117-121.

Allard, R.W., 1990. Principles of plant breeding. John
Wiley \& Sons, New York, USA, 264.

Anonymous, 2020. Department of Agriculture, Cooperation and Farmers Welfare, Ministry of Agriculture and Farmers Welfare, Government of India, Available from https://agricoop.nic.in/en. Accessed on $05^{\text {th }}$ January, 2022.

Anonymous, 2020. FAOSTAT database, Available from https://www.fao.org/faostat/en/\#data/QCL. Accessed on $05^{\text {th }}$ January, 2020.

Bhati, M., Babu, G. S., Rajput, A. S., 2015. Genetic variability, correlation and path coefficient for grain yield and quantitative traits of elite rice (Oryza sativa L.) genotypes at Uttar Pradesh. Electronic Journal of Plant Breeding 6(2), 586-591.

Bhargava, A., Shukla, S., Ohri, D., 2007. Genetic variability and interrelationship among various morphological and quality traits in quinoa (Chenopodium quinoa Willd.). Field Crops Research 101(1), 104-116.

Burton, G.W., Devane, D.E., 1953. Estimating heritability in tall fescue (Festuca arundinacea) from replicated clonal material. Agronomy Journal 45(10), 478-481.

Chakraborty, S., Das, P.K., Guha, B., Barman, B., Sarmah, K.K., 2001. Coheritability, correlation and path analysis and yield component in Boro rice. Oryza 38(3\&4), 99-101.

Das, S., Karak, C., Roy, S., 2020. Genetic variability, correlation and path analysis studies in cowpea [Vigna unguiculata (L.) Walp.]. International Journal of Economic Plants 7(3), 123-128.

Dewey, D.R., Lu, K., 1959. A correlation and path coefficient analysis of components of crested wheatgrass seed production. Agronomy Journal 51(9), 515-518.

Dey, S., Kumar, R., Battan, K.R., Chhabra, A.K., Reddy, A.L., 2021. Study of coefficient of variation, heritability and genetic advance for different traits of rice genotypes grown under aerobic condition. International Journal of Bio-resource and Stress Management 12(5), 426-430.

Fisher, R.A., 1963. Yates statistical tables for biological, agricultural and medical research. Oliver and Boyd, London, UK, 42.

Fukrej, K.P., Kumar, A., Tyagi, W., Rai, M., Pattanayak, A., 2011. Genetic variability in yield and its component in upland rice grown in acid soils of North East India. Journal of Rice Research 4(1), 4-7.

Johnson, H.W., Robinson, H.F., Comstock, R.E., 1955. Genotypic and phenotypic correlations in soybeans and their implications in selection. Agronomy journal 47(10), 477-483.

Krishnamurthy, S.L., Gautam, R.K., Sharma, P.C., Sharma, D.K., 2016. Effect of different salt stresses on agro-morphological traits and utilisation of salt 
stress indices for reproductive stage salt tolerance in rice. Field Crops Research 190, 26-33.

Kumar, A., Nayak, A.K., Das, B.S., Panigrahi, N., Dasgupta, P., Mohanty, S., Kumar, U., Panneerselvam, P., Pathak, H., 2019. Effects of water deficit stress on agronomic and physiological responses of rice and greenhouse gas emission from rice soil under elevated atmospheric $\mathrm{CO}_{2}$. Science of the Total Environment 650, 2032-2050.

Panse, V.C., Sukhatme, P.V., 1978. Statistical methods for agricultural workers. III Rev. Ed. ICAR, New Delhi.

Pathak, H., Nayak, A.K., Jena, M., Singh, O.N., Samal, P., Sharma, S.G., 2018. Rice research for enhancing productivity, profitability and climate resilience. ICAR-National Rice Research Institute, Cuttak, Odisha, India, 542.

Prince, S.J., Beena, R., Gomez, S.M., Senthivel, S., Babu, R.C., 2015. Mapping consistent rice (Oryza sativa L.) yield QTLs under drought stress in target rainfed environments. Rice 8(1), 1-13.

Rashid, M.M., Nuruzzaman, M., Hassan, L., Begam, S.N., 2017. Genetic variability analysis for various yield attributing traits in rice genotypes. Journal of Bangladesh Agricultural University 15(1), 15-19.

Rejeth, R., Manikanta, C.L., Beena, R., Stephen, R., Manju, R.V., Viji, M.M., 2020. Water stress mediated root trait dynamics and identification of microsatellite markers associated with root traits in rice (Oryza sativa L.). Physiology and Molecular Biology of Plants 26(6), 1225-1236.

Roy, R.K., Majumder, R.R., Sultana, S., Hoque, M.E., Ali, M.S., 2015. Genetic variability, correlation and Path
Coefficient analysis for yield and yield component in transplant aman rice (Oryza sativa L.). Bangladesh Journal of Botany 44(4), 529-535.

Searle, S.R., 1961. Phenotypic, genetic and environmental correlations. Biometrics 17(3), 474-480.

Singh, A.K., Nandan, R., Singh, P.K., 2015. Genetic variability and association analysis in rice germplasm under rainfed conditions. Crop Research 47(1 to 3), $7-11$.

Singh, R.K., Chaudhary, B.D., 1977. Biometrical methods in quantitative genetic analysis. Kalyani Publisher, Ludhiana, India, 304.

Sudeepthi, K., Srinivas, T., Kumar, B.R., Jyothula, D.P.B., Umar, S.N., 2020. Assessment of genetic variability, character association and path analysis for yield and yield component traits in rice (Oryza sativa L.). Electronic Journal of Plant Breeding 11(01), 144-148.

Ullah, M.Z., Hasan, M.J., Chowdhury, A., Saki, A., Rahman, A., 2012. Genetic variability and correlation in exotic cucumber (Cucumis sativus L.) varieties. Bangladesh Journal of Plant Breeding and Genetics 25(1), 17-23.

Varshney, R.K., Bansal, K.C., Aggarwal, P.K., Datta, S.K., Craufurd, P.Q., 2011. Agricultural biotechnology for crop improvement in a variable climate: hope or hype?. Trends in Plant Science 16(7), 363-371.

Vennela, M., Srinivas, B., Reddy, V.R., Balram, N., 2021. Studies on correlation and path coefficient analysis in hybrid rice (Oryza sativa L.) for yield and quality traits. International Journal of Bio-Resource and Stress Management 12(5), 496-505. 